\title{
MAPPING AND QUANTITATION OF PROTEINS FROM DISCRETE NUCLEI AND OTHER AREAS OF THE RAT BRAIN BY TWO-DIMENSIONAL GEL ELECTROPHORESIS ${ }^{1}$
}

\author{
WILLIAM E. HEYDORN, ${ }^{*}, 2$ G. JOSEPH CREED, ${ }^{*}$ DAVID GOLDMAN $\ddagger$ DANIEL KANTER, \\ CARL R. MERRIL, $\ddagger$ AND DAVID M. JACOBOWITZ* \\ * Laboratory of Clinical Science and $\ddagger$ Laboratory of General and Comparative Biochemistry, National Institute of Mental Health, \\ Bethesda, Maryland 20205
}

Received May 16, 1983; Revised July 21, 1983; Accepted July 22, 1983

\begin{abstract}
A map of the location and relative concentration of a number of different proteins present in 25 distinct neuroanatomical regions of the male rat brain has been established utilizing two-dimensional polyacrylamide gel electrophoresis. The regions examined include cortical areas as well as nuclei from the hypothalamus, amygdala, thalamus, forebrain, and hindbrain. Tissue samples were obtained from each region of interest by microdissection. Proteins within these samples were first separated by charge using the technique of isoelectric focusing. In the second dimension, proteins were separated by mass on polyacrylamide slab gels containing sodium dodecyl sulfate. Proteins were visualized using a highly sensitive silver stain and quantitated by computerized scanning densitometry. The results demonstrate that all proteins examined varied somewhat in concentration among the different brain regions. The majority $(53 \%)$ of polypeptides selected for quantitation were found to vary less than 4 -fold in concentration between the neuroanatomical areas with the lowest and highest detected amounts. In contrast, approximately $10 \%$ of the proteins examined varied widely in the quantity measured in each brain region, with concentration values ranging more than 10-fold between the regions with the lowest and highest detected amounts. This atlas is a first attempt at systematically classifying the mass, charge, and relative concentration of proteins present in a variety of regions of the rat brain. The system presented here will serve as a basis for future studies in this area.
\end{abstract}

The utility of two-dimensional gel electrophoresis (2DE) as a high resolution tool for separating complex mixtures of proteins by mass and charge was first effectively demonstrated by O'Farrell in 1975 . Since that time, $2 \mathrm{DE}$ has proven to be a useful and powerful research technique, capable of resolving large numbers of proteins based upon their differences in both isoelectric points and molecular weights. Consequently, this methodology has been applied to a variety of research problems. The result has been the publication of normal protein patterns from a number of different peripheral tissues and body fluids (Anderson and Anderson, 1977; Anderson et

\footnotetext{
${ }^{1}$ We would like to thank Mrs. Dorothy Allison for her expert secretarial assistance. W. E. H. is a Research Associate of the Pharmacology-Toxicology Program, National Institute of General Medical Science.

${ }^{2}$ To whom correspondence should be addressed, at Laboratory of Clinical Science, National Institute of Mental Health, Building 10, Room 3D-48, Bethesda, MD 20205.
}

al., 1979, 1982; Merril et al., 1979; Edwards et al., 1981). Such observations provide the framework from which alterations in proteins, induced as a result of either a disease state, the administration of a pharmacologic agent, or an alteration in physiology, can then be examined.

Surprisingly, few investigators have attempted to apply the technique of $2 \mathrm{DE}$ to the separation of proteins from nervous tissue. When attempted, such experiments have generally focused on the detection of an alteration induced as a result of a specific experimental manipulation (Wagner et al., 1979; Deutsch et al., 1980). This work generally does not provide a detailed index of all proteins examined; rather, emphasis is usually placed only upon those that vary as a result of the experimental manipulation (Wagner et al., 1979).

Subpopulations of neuronal tissue have successfully been mapped by 2DE. Examples of this include the soluble proteins from bovine spinal motoneurons (Weil and McIlwain, 1981) and neurofilament proteins from 
rat and mouse central nervous system (Brown et al., 1981). Again, although significant changes among various experimental groups are reported, such studies also fail to provide a generalized index of all proteins normally present in neuronal tissue.

A number of attempts have been made to study postmortem human brain tissue by 2DE. These experiments generally fall into one of two categories-those constructing a map or atlas of proteins present in normal human brain (Comings, 1982; Comings et al., 1982; Kosik et al., 1982) and those endeavoring to ascertain changes induced by a specific disease state (Comings, 1979a, b; Rosenberg et al., 1979, 1981). However, one difficulty with postmortem studies of human brain tissue is that they suffer from the inherent limitation of variability between the time of death and tissue sampling. In addition, little attempt has been made to subdivide tissue on any neuroanatomical basis. Consequently, most results obtained from such studies may contain uncontrolled variables, making interpretation of results difficult (Rosenberg et al., 1979).

Therefore, we initiated a study with the goal of surveying the major proteins visible by silver stain on twodimensional polyacrylamide gels from a variety of discrete neuroanatomical regions of the rat brain. For this study, 25 different regions of the rat brain, including a number of cortical areas as well as nuclei from the hypothalamus, amygdala, thalamus, forebrain, and hindbrain, were chosen. After separating and staining the proteins, the gels were scanned by computerized densitometry, and a number of different proteins were selected for further analysis. The result of this study is an atlas containing the charge, mass, and, when possible, the relative quantity of each of the proteins chosen for analysis. Although some proteins appeared in relatively constant amounts in each of the brain regions, the majority of polypeptides that were examined demonstrated considerable quantitative variation.

\section{Materials and Methods}

Animals and tissue preparation. Male Sprague-Dawley rats (200 to $250 \mathrm{gm}$ ( 45 to 55 days of age); Zivic-Miller Laboratories, Allison Park, PA) were used for all experiments. Animals were maintained on a 12 -h light/dark cycle (lights on at 0600 hours) and had access to food and water ad libitum. In all cases, rats were killed between 0900 and 1200 hours. After decapitation, the brain was rapidly removed from the skull (within $1 \mathrm{~min}$ ) and placed into a brain block. The forebrain was separated from the hindbrain just caudal to the superior colliculus, and both regions were covered with powdered dry ice and allowed to freeze. Using this method, the entire brain was frozen within 3 min. Subsequently, brains were frozen onto microtome specimen plates and cut into sections $300 \mu \mathrm{m}$ thick using a cryostat maintained at $-7^{\circ} \mathrm{C}$. In all cases, the plane of sectioning was kept as close as possible to that in the atlas of König and Klippel (1963).

Tissue sections were dissected for analysis from the frozen coronal sections using the micropunch technique of Palkovits (1973). Cannulas of 1.0, 0.75 and $0.5 \mathrm{~mm}$ internal diameter were used to remove tissue at the
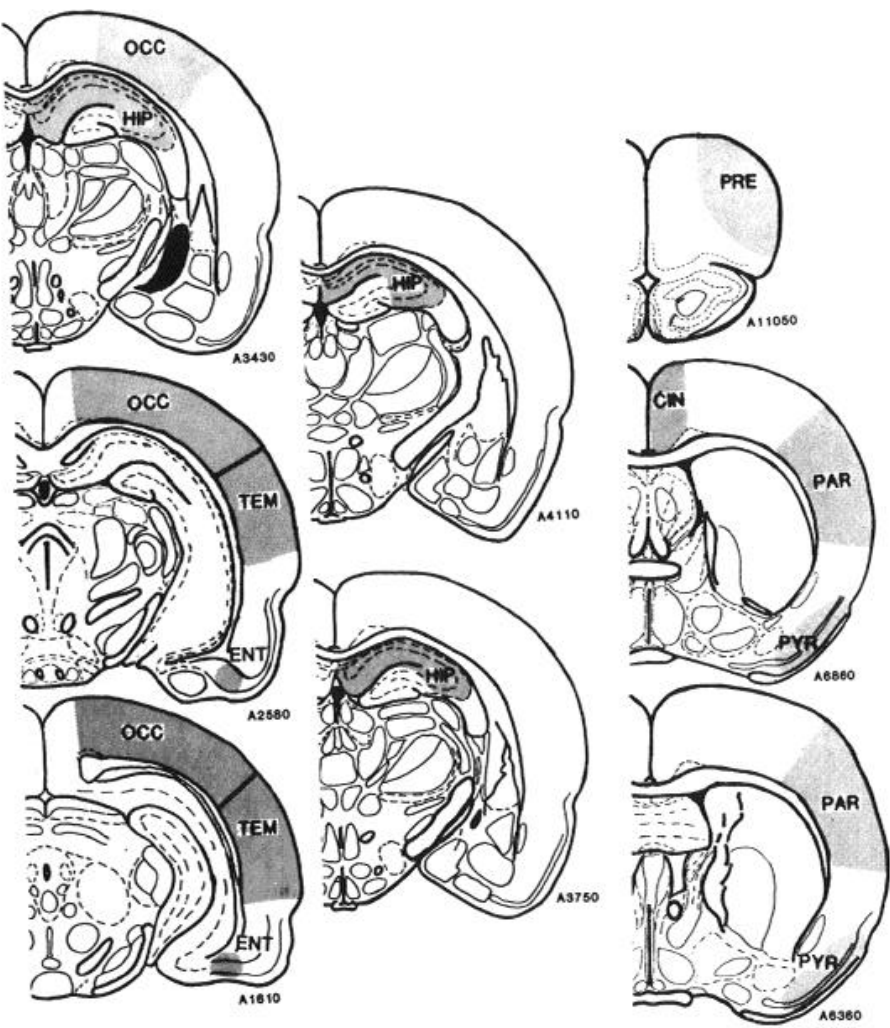

Figure 1. Schematic coronal sections of rat brain showing the location and approximate coordinates of each cortical region analyzed by two-dimensional gel electrophoresis. The stippled areas represent the locations of tissue taken for analysis. Coordinates correspond to those in the atlas of König and Klippel (1963). All cortical regions are shown except cerebellum. Details on the number of tissue punches, cannula sizes, and definition of abbreviations can be found in Table I.

approximate coordinates shown in Figure 1 for cortical areas and Figures 2 and 3 for all other regions. When possible, each region was removed from only one coronal section. The details regarding the numbers of micropunches, animals, and cannula sizes for each neuroanatomical region can be found in Table I.

Microdissected tissue was placed into microfuge tubes (0.4 ml size) containing $0.03 \mathrm{ml}$ of sample detergent solution consisting of (per liter) $55.7 \mathrm{ml}$ of 2-mercaptoethanol (Calbiochem-Behring Corp., La Jolla, CA), 200 $\mathrm{ml}$ of glycerol, $10 \mathrm{ml}$ of a $40 \%$ solution of $3 / 10$ ampholines (Bio-Lyte; Bio-Rad Laboratories, Richmond, CA), $40 \mathrm{ml}$ of a $40 \%$ solution of $5 / 7$ ampholines (Bio-Lyte), and 20 $\mathrm{ml}$ of Nonidet $\mathrm{P}_{40}$ (Bethesda Research Laboratories, Rockville, MD), then briefly sonicated. The homogenate was then frozen at $-70^{\circ} \mathrm{C}$.

Two-dimensional gel electrophoresis. Two-dimensional gel electrophoresis was performed according to the procedure of O'Farrell (1975) with minor modifications. In the first dimension, isoelectric focusing (IEF) was accomplished in tube gels $127.5 \mathrm{~mm} \times 2.5 \mathrm{~mm}$ in size. Gels consisted of $4.75 \%$ acrylamide (Bio-Rad) with $8 \mathrm{M}$ urea and a $4: 1$ ration of $5 / 7$ and $3 / 10$ ampholines (final ampholine concentration of $2 \%$ ). Polymerization was initiated by the addition of a freshly prepared solution of ammonium persulfate (Bio-Rad) and catalyzed with $N, N, N^{\prime}, N^{\prime}$ tetramethylethylenediamine (Bio-Rad). After casting, 

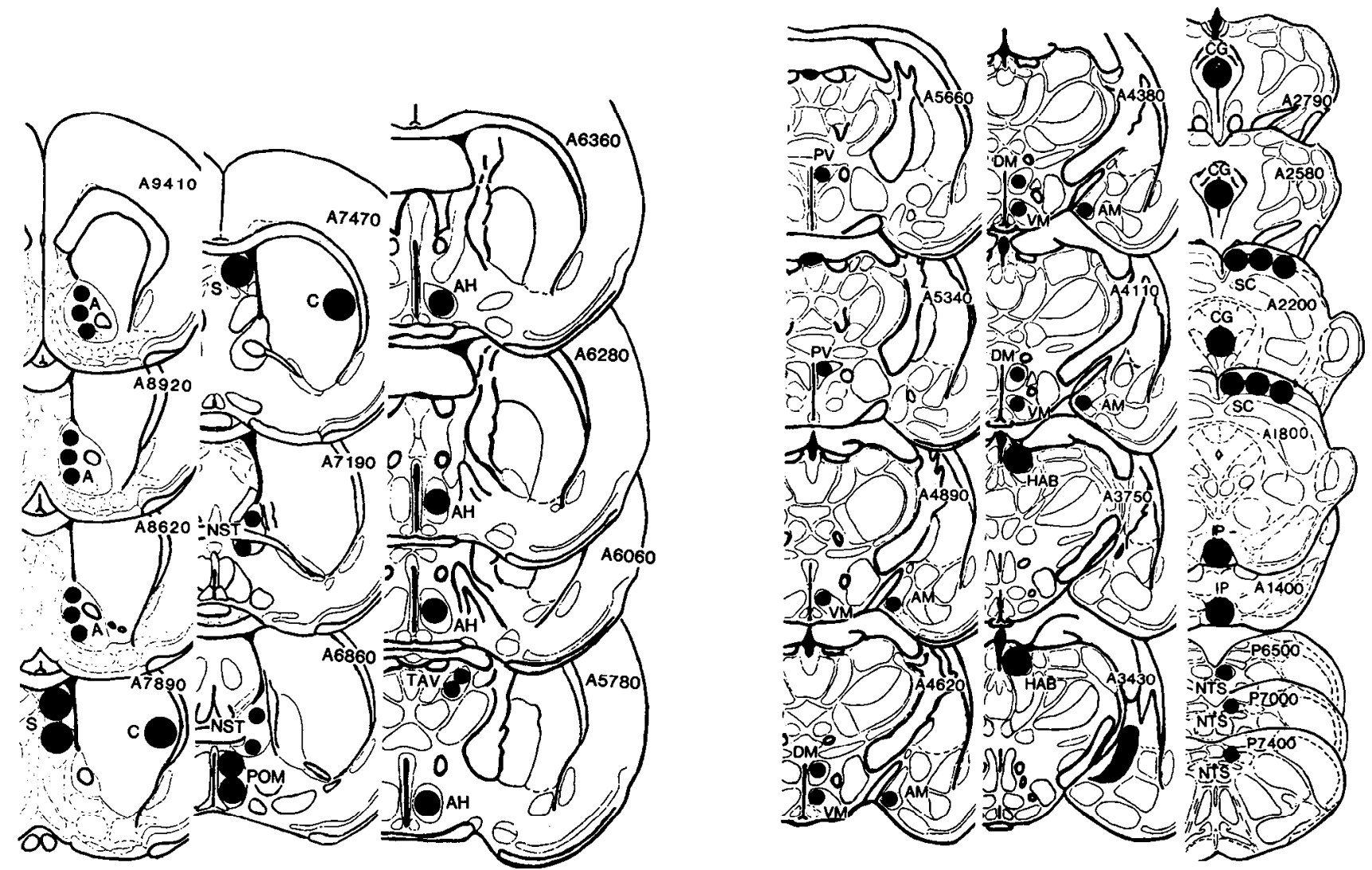

Figures 2 and 3. Schematic coronal sections of rat brain showing the location and approximate coordinates of all areas (except cortices) analyzed by two-dimensional gel electrophoresis. The approximate location of regions dissected and relative cannula sizes are shown by black circles. Coordinates correspond to those in the atlas of König and Klippel (1963). Details on the number of tissue punches, cannula sizes, and definition of abbreviations can be found in Table I.

the tops of the gels were gently overlayed with 0.03 to $0.05 \mathrm{ml}$ of an $8 \mathrm{M}$ urea solution and the gels were then allowed to polymerize for $45 \mathrm{~min}$. Tube gels were then prefocused for $1 \mathrm{hr}$ at $200 \mathrm{~V}$ between an anode solution of $0.01 \mathrm{M} \mathrm{H}_{3} \mathrm{PO}_{4}$ and a cathode solution of degassed 0.03 $\mathrm{M} \mathrm{NaOH}$.

Tissue homogenates were then thawed, and sufficient urea $(15$ to $25 \mathrm{mg})$ was added to make the final urea concentration $8 \mathrm{M}$. After prefocusing, the cathode end of the IEF gel was washed with 0.01 to $0.02 \mathrm{ml}$ of fresh sample detergent solution to remove any remaining $\mathrm{NaOH}$, and tissue samples (range of 0.05 to $0.15 \mathrm{mg}$ of protein in an approximate volume of $0.04 \mathrm{ml}$ ) were loaded onto the gel. Samples were overlayed with $0.01 \mathrm{ml}$ of a solution containing $8 \mathrm{M}$ urea, $5 \%$ Nonidet $\mathrm{P} 40$ and $1 \%$ ampholines (4:1 ratio of $5 / 7$ and 3/10 Bio-Lyte). Freshly degassed $0.03 \mathrm{M} \mathrm{NaOH}$ was added to the cathode chamber, and proteins were focused overnight for approximately 10,000 volt-hours $(500 \mathrm{~V}$ for $20 \mathrm{hr}$ ). Upon completion, gels were gently extruded from the glass tubes and allowed to equilibrate for $1 \mathrm{hr}$ in $16 \mathrm{vol}$ of a solution containing $10 \%$ glycerol, $0.005 \mathrm{M}$ dithiothreitol (Bio$\mathrm{Rad}$ ), and $2.3 \%$ sodium dodecyl sulfate (SDS; Bio-Rad) in $0.0625 \mathrm{M}$ Tris, $\mathrm{pH} 6.8$.

Proteins were separated by molecular weight according to the procedure of Laemmli (1970), using slab gels 140 $\times 110 \mathrm{~mm}$ in size and $0.8 \mathrm{~mm}$ thick. The running gel consisted of $10 \%$ acrylamide and $0.1 \%$ SDS in $0.375 \mathrm{M}$ Tris, $\mathrm{pH}$ 8.8. A stacking gel $(140 \times 25 \mathrm{~mm})$ of $4.75 \%$ acrylamide, $0.1 \%$ SDS, and $0.125 \mathrm{M}$ Tris (pH 6.8) was poured over the running gel after the latter had polymerized. Upon polymerization of the stacking gel, the IEF gel was gently placed on top of the stacking gel, and the two were sealed with $1 \%$ agarose. Electrophoresis was accomplished using a running buffer consisting of $0.025 \mathrm{M}$ Tris, $0.192 \mathrm{M}$ glycine, and $0.1 \%$ SDS. Bromphenol blue was used to monitor the progress of the run. Samples were electrophoresed at a constant current of $20 \mathrm{~mA} / \mathrm{gel}$ until the dye front was within $5 \mathrm{~mm}$ of the base of the running gel. At this point, the current was halted and the slab gels were placed into a tray containing approximately $250 \mathrm{ml}$ of a solution consisting of $50 \%$ methanol, $40 \%$ water, and $10 \%$ acetic acid to fix the proteins within the gel matrix.

Staining. Gels were stained with silver as described previously (Merril et al., 1981a, 1982) with minor modifications. For staining, all procedures were performed in glass trays placed on a slowly oscillating rocker. Each gel was first soaked in $200 \mathrm{ml}$ of a $0.1 \% \quad \mathrm{~K}_{2} \mathrm{Cr}_{2} \mathrm{O}_{7}$ solution containing $0.2 \mathrm{ml} /$ liter of $\mathrm{HNO}_{3}$ for $5 \mathrm{~min}$ and then was transferred to an equal volume of $0.2 \% \mathrm{AgNO}_{3}$ for 25 $\mathrm{min}$. To remove excess silver, each gel was washed in 50 to $100 \mathrm{ml}$ of developer $\left(3 \% \mathrm{Na}_{2} \mathrm{CO}_{3}\right.$ containing $1 \mathrm{ml}$ of $37 \%$ formaldehyde/liter) and then incubated in $200 \mathrm{ml}$ 
TABLE I

Summary of the neuroanatomical regions, map abbreviations, and tissue microdissection parameters used in the mapping of proteins by two-dimensional gel electrophoresis

\begin{tabular}{|c|c|c|c|c|}
\hline Region & $\underset{\text { Mabreviation }}{\text { Map }}$ & $\begin{array}{c}\text { Total } \\
\text { Number of } \\
\text { Punches }\end{array}$ & $\begin{array}{c}\text { Cannula } \\
\text { Size } \\
(\mathrm{mm}) \\
\end{array}$ & $\begin{array}{c}\text { Number } \\
\text { of } \\
\text { Rats }\end{array}$ \\
\hline \multicolumn{5}{|l|}{ I. Cortices } \\
\hline a. Prefrontal & (PRE) & 6 & 1.0 & 1 \\
\hline b. Cingulate & $(\mathrm{CIN})$ & 6 & 1.0 & 1 \\
\hline c. Parietal & (PAR) & 6 & 1.0 & 1 \\
\hline d. Pyriform & (PYR) & 18 & 0.5 & 3 \\
\hline e. Hippocampus & (HIP) & 6 & 1.0 & 1 \\
\hline f. Occipital & (OCC) & 6 & 1.0 & 1 \\
\hline g. 'I'emporal & (TEM) & 6 & 1.0 & 1 \\
\hline h. Entorhinal & (ENT) & 18 & 0.5 & 3 \\
\hline i. Cerebellum & (CER) & 6 & 1.0 & 1 \\
\hline \multicolumn{5}{|l|}{ II. Forebrain } \\
\hline a. N. Accumbens & (A) & 16 & 0.5 & 1 \\
\hline b. Septal Area & (S) & 6 & 1.0 & 1 \\
\hline c. Caudate & (C) & 6 & 1.0 & 1 \\
\hline $\begin{array}{l}\text { d. N. Interstitialis } \\
\text { Stria Terminalis }\end{array}$ & (NST) & 24 & 0.5 & 3 \\
\hline Preoptic Area & & & & \\
\hline $\begin{array}{l}\text { e. Preoptic Medial } \\
\text { N. }\end{array}$ & (POM) & 8 & 0.75 & 2 \\
\hline \multicolumn{5}{|l|}{ Hypothalamus } \\
\hline $\begin{array}{ll}f . & \text { Anterior } \\
& \text { Hypothalamic N. }\end{array}$ & $(\mathrm{AH})$ & 8 & 0.75 & 2 \\
\hline $\begin{array}{l}\text { g. Paraventricular } \\
\text { N. }\end{array}$ & $(\mathrm{PV})$ & 16 & 0.5 & 4 \\
\hline$h$. Ventromedial N. & (VM) & 12 & 0.5 & 2 \\
\hline $\begin{array}{l}i \text {. Dorsomedial N. } \\
\text { Thalamus }\end{array}$ & $(\mathrm{DM})$ & 4 & 0.5 & 2 \\
\hline $\begin{array}{l}j . \text { Anterior Ventral } \\
\text { N. Thalamus }\end{array}$ & (TAV) & 12 & 0.5 & 3 \\
\hline $\begin{array}{l}\text { k. Habenula } \\
\text { Amygdala }\end{array}$ & (HAB) & 4 & 1.0 & 1 \\
\hline l. Medial Amygdala & $(\mathrm{AM})$ & 18 & 0.5 & 3 \\
\hline $\begin{array}{l}\text { III. Midbrain } \\
\text { a. Central Gray }\end{array}$ & $(\mathrm{CG})$ & 6 & 1.0 & 2 \\
\hline $\begin{array}{l}\text { a. Central Gray } \\
b \text {. Superior } \\
\text { Colliculus }\end{array}$ & $\begin{array}{l}\text { (CG) } \\
(\mathrm{SC})\end{array}$ & $\begin{array}{r}0 \\
12\end{array}$ & $\begin{array}{l}1.0 \\
0.75\end{array}$ & $\begin{array}{l}2 \\
1\end{array}$ \\
\hline $\begin{array}{l}\text { c. Interpenduncular } \\
\mathrm{N} \text {. }\end{array}$ & (IP) & 6 & 1.0 & 3 \\
\hline $\begin{array}{l}\text { IV. Hindbrain } \\
\text { a. N. Tractus } \\
\text { Solitarius }\end{array}$ & (NTS) & 18 & 0.5 & 3 \\
\hline
\end{tabular}

of this solution until the gel background began to turn yellow (8 to $10 \mathrm{~min}$ ). Developing was stopped with $3 \%$ acetic acid. The gels were then washed twice $(10 \mathrm{~min}$ each) with water and stored in polyethylene bags.

Analysis of polyacrylamide gels. Quantitative analysis of individual protein spots was accomplished by computer-assisted densitometry based upon the procedure of Goldman et al. (1982). Each gel was first photographed next to a calibrated density standard (National Bureau of Standards, Gaithersburg, MD) using $120-\mathrm{mm}$ Tri-X Kodak film. For computerized densitometry, a PDP-11/ 60 computer (Digital Equipment, Maynard, MA) equipped with an IP 5000 image processor (De Anza Systems, San Jose, CA) with three $512 \times 512 \times 8$ image arrays was used. Negatives were digitized with a 1000
HS scanning microdensitometer (Optronics, Chelmsford, MA) at the 0 to 2 optical density setting and $100 \mu \mathrm{m}$ resolution, and then normalized to the calibrated photographic standard.

For measurements, a computer program requiring an operator to successively measure each gel for a particular protein was employed. Patterns of proteins common in all gels were used for orientation, and a measurement window was then positioned over the protein of interest. The measurement window consisted of an inner polygon to calculate the density, area, and coordinates of the polypeptide, and a larger outer polygon for calculation of background. The size and shape of both polygons could be varied when needed, but were generally held constant throughout measurements for any particular protein. After a spot was measured in one gel, the next gel in the series was automatically displayed on the video screen and the measurement window was quickly repositioned (if needed). The density of each protein was calculated based upon the following formula: [(average density within the inner polygon) minus (background density)] $x$ area of inner polygon (in $\mathrm{mm}^{2}$ ), where background density is the modal density of the picture elements in the outer polygon. Consequently, units for density are optical density $\times \mathrm{mm}^{2}$.

At the conclusion of the analysis, protein densities were normalized based on the procedure of Goldman et al. (1982) by calculating a normalization ratio for each gel. This was accomplished by selecting 43 nonsaturating protein spots on each gel, summing their densities, and comparing this value to that obtained in one randomly chosen reference gel. This ratio (which is unique for each gel) is then used to correct initial optical density measurements. This procedure is necessary because of dayto-day differences in the amount of protein loaded onto each gel and variations in the density of the silver stain among individual gels.

Standardization of gels. The approximate molecular weight of each protein measured was calculated using a low molecular weight protein standard kit (Pharmacia, Piscataway, NJ) consisting of the following proteins and molecular weights: phosphorylase $b(94,000)$, albumin $(67,000)$, ovalbumin $(43,000)$, carbonic anhydrase $(30,000)$, soybean trypsin inhibitor $(20,100)$, and $\alpha$-lactalbumin $(14,400)$. These standards were run on a slab gel, and a migration distance relative to the dye front was calculated and used for molecular weight determination.

The isoelectric gradient of the tube gels was calculated according to the procedure of Goldman et al. (1980), using tube gels on which $0.15 \mathrm{mg}$ of parietal cortex tissue had been focused. The gels were cut into $3-\mathrm{mm}$ segments, and the $\mathrm{pH}$ of each slice was determined. The final $\mathrm{pH}$ gradient is based on an average of three determinations.

Statistical analysis of data. When necessary, optical density measurements among different neuroanatomical brain regions were compared using a two-tailed Student's $t$ test.

\section{Results}

A representative two-dimensional polyacrylamide gel obtained when tissue samples from the central nervous 
system were electrophoresed under the conditions described above is shown in Figure 4. The patterns of protein spots visible in this gel are representative of those found in all of the neuroanatomical regions that were examined in this study. Differences in the intensity of staining of each protein, and hence the relative quantity of each protein, could be demonstrated among the different regions. These differences are discussed in more detail below.

Figure $5 A$ shows the location of each protein chosen for computerized densitometric examination in this

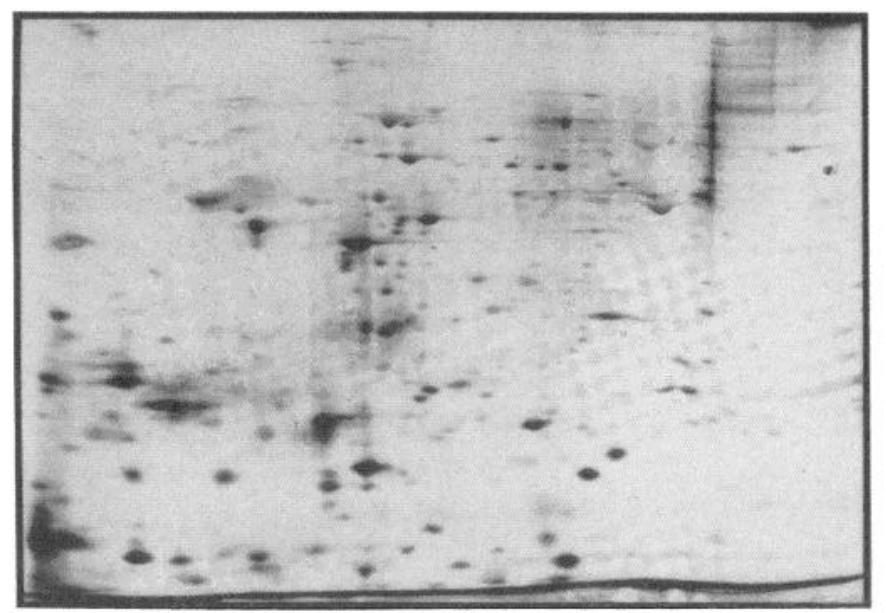

Figure 4. Representative silver-stained two-dimension polyacrylamide gel generated when tissue samples from the central nervous system were electrophoresed under the conditions described under "Materials and Methods." For orientation purposes, the molecular weight range visible on this gel is approximately 100,000 (at the top of the gel) to 10,000 (at the base of the gel). The $\mathrm{pH}$ of proteins visible on this gel is 4.75 (left side of the gel) to 7.0. Tissue from the hippocampus was used in generating this particular gel.

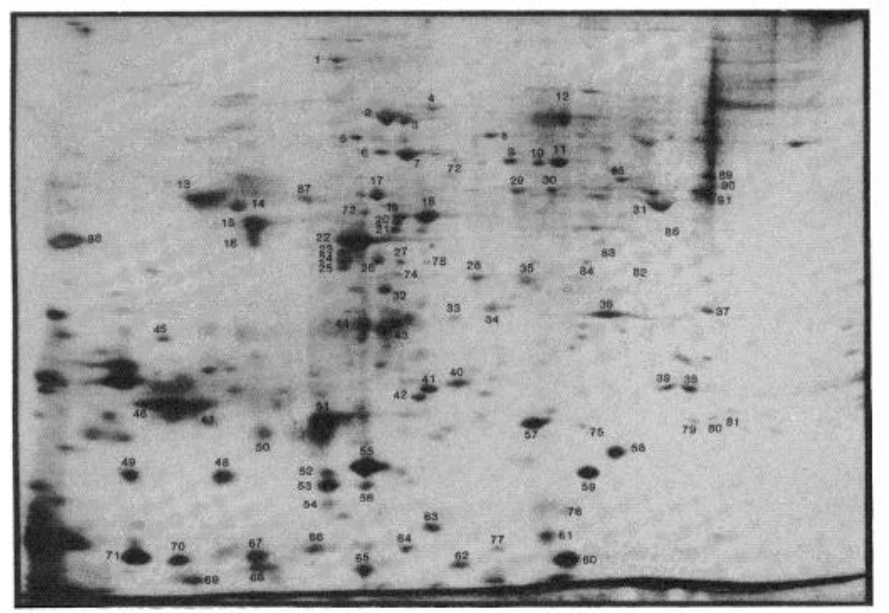

study. Each protein that was measured was assigned a permanent indexing number, and these are indicated next to the polypeptides they represent. This numbering system can then be used when identifying specific proteins for more detailed study. As can be seen from this photograph, a large quantity of proteins representing all areas of the gel were selected for analysis.

In order to locate more clearly protein spots and compare quantitative variations for each protein, computerdrawn diagrams were constructed for each neuroanatomical region. An example of one of these diagrams can be seen in Figure $5 B$. In this diagram, the location of each protein was determined by its location on a reference gel (in this study, a hippocampal gel was used for this purpose). In addition, the ordinate and abscissa are marked for molecular weight and isoelectric range, respectively. The size of the ellipses seen in Figure $5 B$ is dependent on the optical density measurement for that protein. These computer-drawn diagrams allow comparisons of the relative quantity of proteins both within a particular region and among different regions.

The data on the apparent molecular weight, isoelectric point, and relative amount of most proteins examined in this study are summarized in Table II. In all cases, densitometric analysis was performed on three gels from each of the 25 different brain regions. The optical density values presented in this table represent only the range of measurements obtained for each protein and the regions containing the lowest and highest values measured. As can be seen from this table, several proteins appear to be present in relatively constant amounts in all 25 regions examined. Examples of this include proteins numbered $18,41,46$, and 58 , all of which vary by less than 2 -fold among the different brain regions examined. In contrast, some proteins were found to vary quite widely in this study, being present in significant concen-

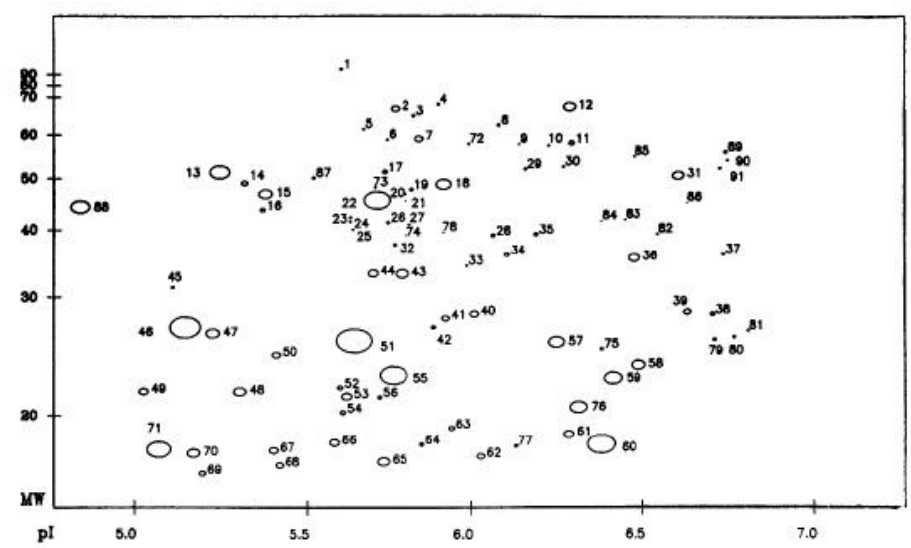

Figure 5. A, Representative silver-stained two-dimension polyacrylamide gel generated when hippocampal tissue was electrophoresed under the conditions described under "Materials and Methods," showing the location and permanent indexing number of each protein selected for densitometric examination. Most proteins selected for analysis are visible on this gel. In cases where proteins are almost totally absent from this gel (e.g., proteins numbered 82 and 86 ), the approximate location, based upon analysis of gels from other neuroanatomical regions, is noted. $B$, Computer-drawn diagram constructed to aid in the analysis of densitometric data. The location of each protein on this diagram is determined by its location on a reference gel from the hippocampus. In addition, the ordinate and abscissa are marked for molecular weight $(M W)$ and isoelectric range $(p I)$, respectively. The size of each ellipse is dependent on the optical density measurement for that protein. In this particular example, the size of each ellipse represents the mean of three densitometric determinations of gels from the hippocampus. 
TABLE II

Isoelectric points, molecular weights, and range of optical density values for each protein examined by two-dimensional gel electrophoresis with computerized scanning densitometry

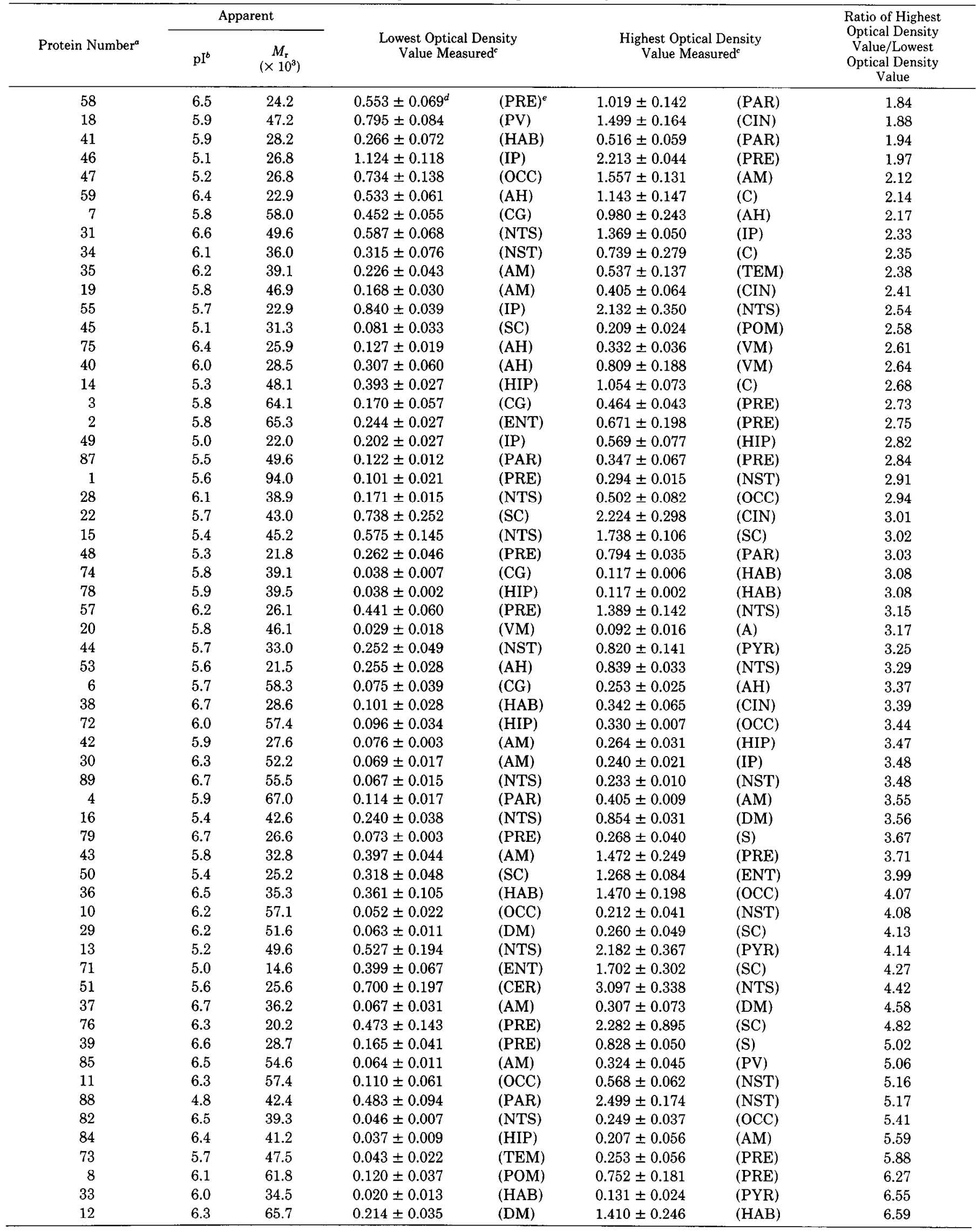


Table II (continued)

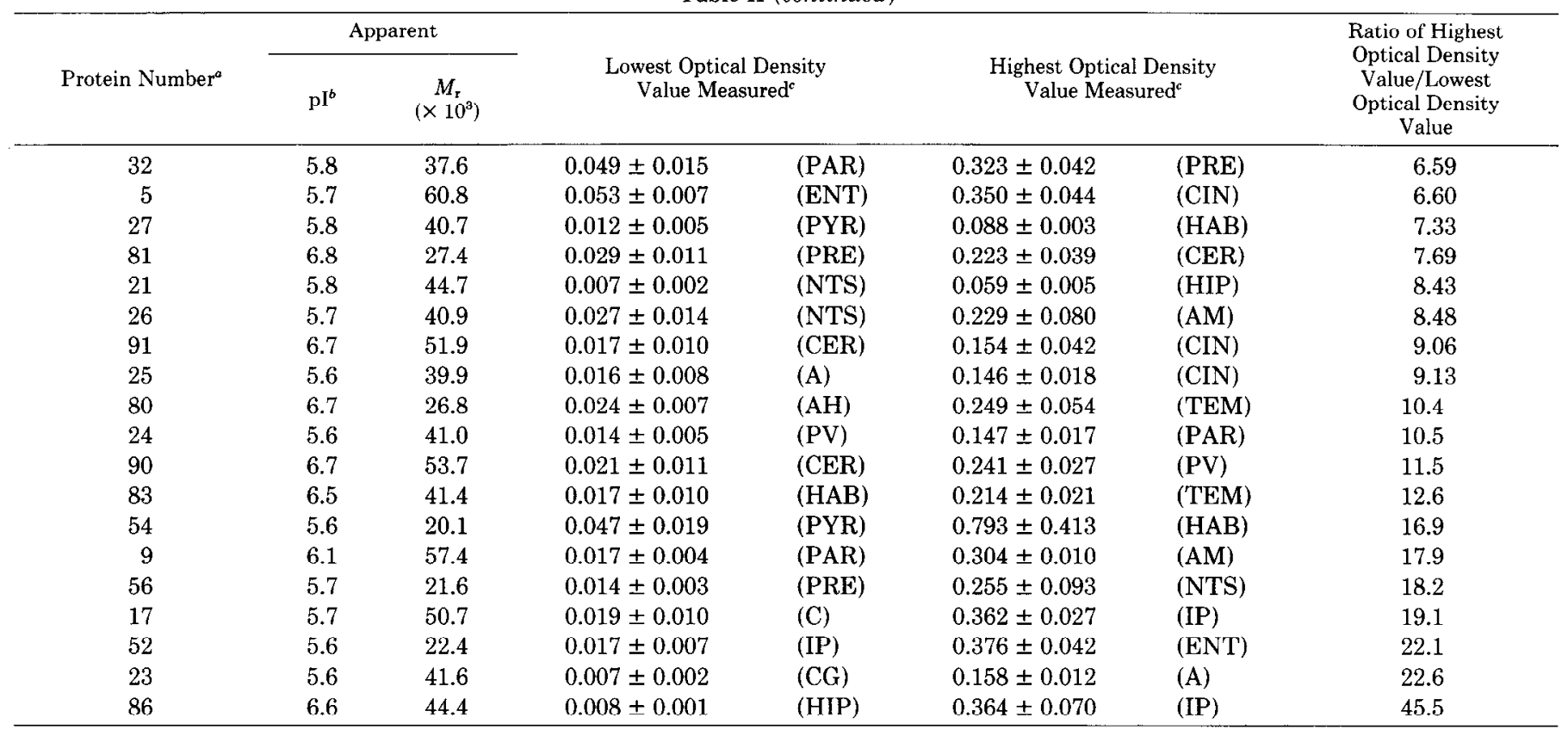

${ }^{a}$ Corresponds with the numbering system in Figure $5, A$ and $B$.

${ }^{b}$ Isoelectric point was determined under the conditions summarized under "Materials and Methods."

' The corresponding neuroanatomical region is given in parentheses.

${ }^{d} \overline{\mathrm{X}} \pm$ SEM of three separate determinations. All units are optical density times square millimeters. For explanation, see the text.

- Abbreviations are defined in Table I.

trations in one or more of the neuroanatomical regions while almost totally absent from other areas. Examples include proteins numbered 23,52 , and 86 , all of which vary by more than 20 -fold between the regions with the lowest and highest density.

Unfortunately, optical density values could not be obtained for all 91 proteins from each of the 25 neuroanatomical regions chosen for study. Most proteins with $M_{\mathrm{r}}<20,000$ were not adequately and consistently separated from the bromphenol blue dye front on the seconddimension gel to allow an accurate computer analysis of both the spot density and the surrounding background density. In addition, the fixation of these proteins in the gel matrix, and resultant staining with silver, appeared to vary widely from one electrophoretic run to the next. Therefore, the complete range of optical density values for these proteins from all neuroanatomical regions could not be determined, and is not included in Table II. However, a summary of the isoelectric points and molecular weights of these proteins is presented in Table III.

Many photographic examples of the variability of individual proteins among the different brain regions could be presented. Two representative examples are shown in Figures 6 and 7. Figure 6 shows pictorial evidence of the variability found in protein number 17 . This protein, with an apparent $M_{\mathrm{r}}$ of 50,700 and $\mathrm{pI}$ of 5.7, was detected in relatively large amounts in only two neuroanatomical regions - the interpeduncular nucleus $(\mathrm{OD}=0.362)$ and the hippocampus $(\mathrm{OD}=0.293$ ). These values are approximately $30 \%$ higher than those found in any other brain area studied. Figure 6 demonstrates the variability of this protein by comparing sections of representative two-dimension gels of the interpeduncular nucleus and
TABLE III

Isoelectric points and molecular weights for those proteins on which a complete optical density analysis could not be made

\begin{tabular}{cccccc}
\multirow{2}{*}{ Protein Number $^{a}$} & \multicolumn{2}{c}{ Apparent } & \multirow{2}{*}{ Protein Number } & \multicolumn{2}{c}{ Apparent } \\
\cline { 2 - 3 } & $\mathrm{pl}^{\mathrm{b}}$ & $M_{\mathrm{r}}\left(\times 10^{3}\right)$ & & $\mathrm{pI}$ & $M_{\mathrm{r}}\left(\times 10^{3}\right)$ \\
\hline 60 & 6.3 & 15.1 & 66 & 5.6 & 16.1 \\
61 & 6.3 & 17.0 & 67 & 5.4 & 15.1 \\
62 & 6.0 & 14.4 & 68 & 5.4 & 13.2 \\
63 & 5.9 & 18.0 & 69 & 5.2 & 12.1 \\
64 & 5.8 & 16.1 & 70 & 5.2 & 14.6 \\
65 & 5.7 & 13.5 & 77 & 6.1 & 15.9 \\
\hline
\end{tabular}

${ }^{\circ}$ Corresponds with the numbering system in Figure $5, A$ and $B$.

${ }^{b}$ Isoelectric point determined under the conditions summarized under "Materials and Methods."

the hippocampus to a section from a gel of the parietal cortex. In this example, the measured optical densities of proteins numbered 18 and 19 did not vary significantly among the three different brain regions. As is readily evident, the apparent concentration of protein number 17 in the parietal cortex is less than that in either of the other two brain regions. This is confirmed when comparing the calculated optical density value for this protein in the parietal cortex $(\mathrm{OD}=0.080)$ to that in either the interpeduncular nucleus $(p<0.005)$ or the hippocampus $(p<0.005)$.

A second photographic example of a variable protein encountered in this study is seen in Figure 7. This figure shows the variation seen in protein number 52 (apparent $M_{\mathrm{r}}=22,400, \mathrm{pI}=5.6$ ). Similar to the example cited above, this protein is found in relatively large amounts in only two brain regions-the entorhinal cortex $(\mathrm{OD}=$ $0.376)$ and the hippocampus ( $O D=0.318)$. These values 


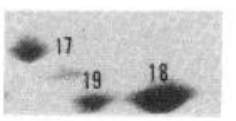

HIPPOCAMPUS

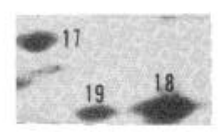

INTERPEDUNCULAR NUCLEUS

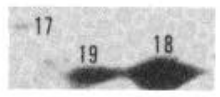

\section{PARIETAL CORTEX}

Figure 6. Composite picture showing the variability in the apparent concentration of protein number 17 among different neuroanatomical regions of the rat brain. Tissue from the hippocampus, interpeduncular nucleus, and parietal cortex was electrophoresed as described under "Materials and Methods." The measured optical density of proteins numbered 18 and 19 did not vary significantly among the different brain regions. Protein number 17, which was found in significant amounts in the hippocampus and the interpeduncular nucleus, is almost totally absent from the parietal cortex.

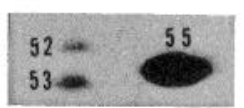

ENTORHINAL CORTEX

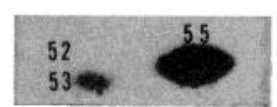

DORSOMEDIAL NUCLEUS
Figure 7. Composite picture showing the variability in the apparent concentration of protein number 52 among different neuroanatomical regions of the rat brain. Tissue from the entorhinal cortex and dorsomedial nucleus of the hypothalamus was electrophoresed as described under "Materials and Methods." The measured optical density of proteins numbered 53 and 55 did not vary significantly between the two brain regions. Protein number 52, which was detected in significant amounts in the entorhinal cortex, is almost totally absent from the dorsomedial nucleus of the hypothalamus.

are $50 \%$ higher than those detected in any other neuroanatomical region. Figure 7 illustrates the variability of this protein by comparing a representative section from a gel obtained when tissue from the entorhinal cortex is electrophoresed to that seen when tissue from the dorsomedial nucleus of the hypothalamus is electrophoresed. In this example, proteins numbered 53 and 55 are found in approximately equal amounts in both brain areas. Protein number 52, however, appears to be almost totally absent from the dorsomedial nucleus of the hypothalamus, whereas it is found in significant amounts in the entorhinal cortex. This is confirmed when comparing the calculated optical density value for this protein in the dorsomedial nucleus of the hypothalamus $(\mathrm{OD}=0.051)$ to that in the entorhinal cortex $(p<0.005)$.

\section{Discussion}

These results represent an initial attempt at systematically organizing the proteins visible on two-dimensional polyacrylamide gels from different neuroanatomical regions in the rat brain. Previous studies in this area have either focused on the mapping of proteins from subpopulations of neuronal tissue (Brown et al., 1981; Weil and McIlwain, 1981) or have looked for alterations in proteins from neuronal tissue induced by a disease state (Comings, 1979a, b; Rosenberg et al., 1979, 1981) or an experimental manipulation (Wagner et al., 1979; Deutsch et al., 1980; Perry and Wilson, 1981). This report expands upon these previous studies by presenting the basis for a generalized system that will be used in future studies that deal with the classification of proteins from neuronal tissue.

The present results also demonstrate that there exist marked differences in the apparent amount of individual proteins visible on two-dimensional polyacrylamide gels among various neuroanatomical regions of the rat brain. As can be seen in Table II, several of the proteins selected for computer-assisted analysis varied widely in concentration among the 25 regions under study. Such data are consistent with previous work (Caplan et al., 1974) demonstrating significant quantitative differences among mammalian brain proteins from different neuroanatomical regions as seen after one-dimensional electrophoresis. Figures 6 and 7 of the present report show pictorial evidence of two of the many examples of the variability encountered in this study. It is interesting to note that the variability was not limited to proteins present in either relatively large or small amounts; rather, both densely and lightly staining proteins were found to show wide differences in concentration among the different brain regions that were studied.

Unfortunately, it was not possible to perform manual densitometric analysis on every protein visible on our two-dimension gels. Thus, only a limited number of proteins were chosen for analysis. Several criteria were employed when deciding which of the proteins to choose for densitometric examination. First, proteins had to be present in significant concentrations in one or (preferably) more neuroanatomical regions so that they were distinguished from the background staining of the gel. Second, proteins had to be well resolved from any surrounding proteins on all gels so that an accurate measurement of the staining density could be made. Finally, proteins chosen for analysis had to represent a large range of molecular weights and isoelectric points. Based upon these criteria, the 91 well resolved proteins indicated in Figure $5 A$ were selected for quantitative analysis.

The absolute identity of the majority of the 91 proteins selected for densitometric analysis is unknown. Tentative assignments, based on previously published reports (Wilson et al., 1977; Hall et al., 1978; Merril et al., 1981b; Weil and McIlwain, 1981; Goldman et al., 1982) can be made for actin (spot 22) and $\beta$-tubulin (spot 13). In addition, spot 12 may represent serum albumin contamination of our tissue samples, a problem encountered by others (Wilson et al., 1977; Weil and McIlwain, 1981). Future experiments will be aimed at identifying and learning more about many of the other proteins visible on these two-dimensional gels.

Although these results are a significant first step in the electrophoretic examination of proteins present in neuronal tissue, they represent only a very small percentage of the total amount of work that will be necessary to fully classify proteins present in rat brain. We have examined only a small number of the most readily visible proteins from a limited number of neuroanatomical re- 
gions. Close inspection of the best two-dimensional polyacrylamide gels that were generated in this study shows that more than 300 proteins are able to be seen. This, however, most likely represents only a small fraction of the total number of proteins present in rat brain. Estimates of the number of different messenger RNA sequences present in mammalian brain, and thus the theoretical total number of different possible proteins, are in excess of 100,000 (Bantle and Hahn, 1976; Chikaraishi, 1979). Thus, even taking into account the recent suggestion that the majority of messenger RNAs present in mammalian cells may only rarely, if ever, be translated (Duncan and McConkey, 1982), the mapping and quantitative analysis presented here still represent only a small fraction of the total number of proteins present in rat brain.

Fortunately, there are several experimental manipulations that could easily be used to expand this atlas of proteins. First, by altering the $\mathrm{pH}$ range of the first dimension, proteins with either a more acidic or a basic isoelectric point would become visible. Currently, these proteins are located on the lateral margins of the seconddimension gels, making accurate computer analysis impossible. By changing the $\mathrm{pH}$ range of the ampholines in the first dimension, these proteins could be moved toward the center of the gel, allowing a more complete analysis of each of them. Additionally, by employing the technique of non-equilibrium gel electrophoresis (O'Farrell et al., 1977), a greater number of proteins, especially in the basic $\mathrm{pH}$ range, should be able to be visualized.

A second way to expand the number of proteins visible is to alter the concentration of acrylamide in the second dimension, thereby changing the molecular weight range which is detected. Using the methodology above, the molecular weight range that is visible is $\sim 100,000$ to 10,000 . Proteins with $M_{\mathrm{r}}>100,000$ form streaks, rather than distinct spots, in the upper part of the seconddimension gel (Duncan and McConkey, 1982) and consequently are difficult to measure. Reducing the acrylamide concentration should make it possible to detect proteins with $M_{\mathrm{r}}>100,000$. Conversely, in our system, polypeptides with $M_{\mathrm{r}}<10,000$ run with the dye front on the second-dimension gel and cannot be visualized, whereas those proteins with $M_{\mathrm{r}}=10,000$ to 20,000 are not consistently distinguishable from the dye front. By increasing acrylamide concentration and adjusting the acrylamide/bis-acrylamide ratio in the second dimension, it may be possible to detect proteins with $M_{\mathrm{r}}$ down to 2,000 (Swank and Munkres, 1971). Visualization and quantitation of both larger and smaller molecular weight proteins will be essential in compiling a complete atlas of brain proteins.

In addition to altering the molecular weight and isoelectric point range of our gels, a variety of other options are available to detect a greater percentage of the proteins present in the central nervous system. Subcellular fractionation of samples prior to electrophoresis would be useful in determining the location within cells of each polypeptide under study, and might reveal clues as to the possible role of each protein in the maintenance of cellular homeostasis. This will also result in the ability to concentrate proteins to a greater degree, possibly reveal- ing polypeptides which, because they are present in such small amounts, are not seen on our gels.

Finally, there are other limitations to this work. Using the silver stain technique, proteins present in concentrations of approximately $20 \mathrm{pg} / \mathrm{mm}^{2}$ or more can be detected (Merril et al., 1982). Refined and improved staining techniques will produce greater sensitivity, revealing proteins present in smaller concentrations for study. In addition, the silver stain reveals information only about the concentration of proteins under study. In vivo and in vitro autoradiographic experiments could be employed in an attempt to discover more information about the rate of synthesis and turnover of each protein. Also, on a strict neuroanatomical basis, the brain can be dissected into hundreds of precise subdivisions (König and Klippel, 1963). We have chosen only 25 different regions for this initial study, representing a variety of different areas. Obviously, it will be necessary, to produce a complete neuroanatomical protein atlas, to examine far more than the relatively few regions chosen for this study.

In spite of these limitations, this atlas of brain proteins will serve as a basis for future studies on proteins from the central nervous system. Computer analysis allows accurate comparisons of both quantitative and qualitative differences among various regions, opening up new areas for research. For example, it has already been successfully demonstrated that the concentrations of at least two proteins in rat brain visible by $2 \mathrm{DE}$ are reduced by the repeated administration of the tricyclic antidepressant desmethylimipramine (W. E. Heydorn, G. J. Creed, and D. M. Jacobowitz, manuscript in preparation). In the future, it is hoped that efforts will be directed at expanding these data by increasing the number of protcins measured, examining a greater number of neuroanatomical regions, and determining the possible function of each of the proteins detected in these studies.

\section{References}

Anderson, L., and N. Anderson (1977) High resolution twodimensional electrophoresis of human plasma proteins. Proc. Natl. Acad. Sci. U. S. A. 74: 5421-5425.

Anderson, N. G., N. L. Anderson, and S. L. Tollaksen (1979) Proteins from human urine. I. Concentration and analysis by two-dimensional electrophoresis. Clin. Chem. 25: 11991210.

Anderson, N. G., M. T. Powers, and S. L. Tollaksen (1982) Proteins in human milk. I. Identification of major components. Clin. Chem. 28: 1045-1055.

Bantle, J. A., and W. E. Hahn (1976) Complexity and characterization of polyadenylated R.N.A. in the mouse brain. Cell 8: $139-150$.

Brown, B. A., R. A. Nixon, P. Strocchi, and C. A. Marotta (1981) Characterization and comparison of neurofilament proteins from rat and mouse CNS. J. Neurochem. 36: 143150.

Caplan, R., S. Cheung, and G. S. Omenn (1974) Electrophoretic profiles of aqueous-soluble proteins of human cerebral cortex: Population and developmental characteristics. J. Neurochem. 22: 517-520.

Chikaraishi, D. M. (1979) Complexity of cytoplasmic polyadenylated and nonpolyadenylated rat brain ribonucleic acids. Biochemistry 18: 3249-3256.

Comings, D. E. (1979a) A search for the mutant proteins in 
Huntington's Disease and schizophrenia. Adv. Neurol. 23: 335349.

Comings, D. E. (1979b) Pc 1 duarte, a common polymorphism of a human brain protein, and its relationship to depressive disease and multiple sclerosis. Nature (Lond.) 277: 28-32.

Comings, D. E. (1982) Two-dimensional gel electrophoresis of human brain proteins. I. Techniques and nomenclature of proteins. Clin. Chem. 28: 782-789.

Comings, D. E., N. G. Carraway, and A. Pekkula-Flagan (1982) Two-dimensional gel electrophoresis of human brain proteins. II. Specific proteins and brain subfractions. Clin. Chem. 28: 790-797.

Deutsch, D. G., N. Schechter, W. Brecha, W. Quitschke, P. Schulman, M. Cane, M. Gazzaniga, and M. V. Simpson (1980) Analysis of protein levels and synthesis after learning in the split-brain pigeon. Brain Res. 198: 135-145.

Duncan, R., and E. H. McConkey (1982) How many proteins are there in a typical mammalian cell? Clin. Chem. 28: 749755.

Edwards, J. J., S. L. Tollaksen, and N. G. Anderson (1981) Proteins of human semen. I. Two-dimensional mapping of human seminal fluid. Clin. Chem. 27: 1335-1340.

Goldman, D., C. R. Merril, and M. H. Ebert (1980) Twodimensional gel electrophoresis of cerebrospinal fluid proteins. Clin. Chem. 26: 1317-1322.

Goldman, D., C. R. Merril, R. J. Polinsky, and M. H. Ebert (1982) Lymphocyte proteins in Huntington's Disease: Quantitative analysis by use of two-dimensional electrophoresis and computerized densitometry. Clin. Chem. 28: 1021-1025.

Hall, M. E., D. L. Wilson, and G. C. Stone (1978) Changes in synthesis of specific proteins following axotomy: Detection with two-dimensional gel electrophoresis. J. Neurobiol. 9: 353-366.

König, J. F. R., and R. A. Klippel (1963) The Rat Brain: A Stereotaxic Allas of the Forebrain and Lower Parts of the Brain Stem, The Williams \& Wilkins Co., Baltimore.

Kosik, K. S., J. M. Gilbert, D. J. Selkow, and P. Strocchi (1982) Characterization of postmortem human brain proteins by two-dimensional gel electrophoresis. J. Neurochem. 39: 15291538.

Laemmli, U. K. (1970) Cleavage of structural proteins during the assembly of the head of bacteriophage T4. Nature (Lond.) 227: $680-685$.

Merril, C. R., R. C. Switzer, and M. L. VanKeuren (1979) Trace polypeptides in cellular extracts and human body fluids de- tected by two-dimensional electrophoresis and a highly sensitive silver stain. Proc. Natl. Acad. Sci. U. S. A. 76: 43354339.

Merril, C. R., D. Goldman, S. A. Sedman, and M. H. Ebert (1981a) Ultrasensitive stain for proteins in polyacrylamide gels shows regional variation in cerebrospinal fluid proteins. Science 211: 1437-1438.

Merril, C. R., D. Goldman, and M. Ebert (1981b) Protein variations associated with Lesch-Nyhan syndrome. Proc. Natl. Acad. Sci. U. S. A. 78: 6471-6475.

Merril, C. R., D. Goldman, and M. L. VanKeuren (1982) Simplified silver protein detection and image enhancement in polyacrylamide gels. Electrophoresis $3: 17-23$.

O'Farrell, P. H. (1975) High resolution two-dimensional electrophoresis of proteins. J. Biol. Chem. 250: 4007-4021.

O'Farrell, P. Z., H. M. Goodman, and P. H. O'Farrell (1977) High resolution two-dimensional electrophoresis of basic as well as acidic proteins. Cell 12: 1133-1142.

Palkovits, M. (1973) Isolated removal of hypothalamic or other brain nuclei of the rat. Brain Res. 59: 449-450.

Perry, G. W., and D. L. Wilson (1981) Protein synthesis and axonal transport during nerve regeneration. J. Neurochem. 37: $1203-1217$.

Rosenberg, R. N., L. Thomas, F. Baskin, J. Kirkpatrick, C. Bay, and W. Nyhan (1979) Joseph Disease: Protein patterns in fibroblasts and brain. Neurology 29: 917-926.

Rosenberg, R. N., N. Ivy, J. Kirkpatrick, C. Bay, W. I. Nyhan, and F. Baskin (1981) Joseph Disease and Huntington Disease: Protein patterns in fibroblasts and brain. Neurology 31: 1003-1014.

Swank, R. T., and K. D. Munkres (1971) Molecular weight analysis of oligopeptides by electrophoresis in polyacrylamide gel with sodium dodecyl sulfate. Anal. Biochem. 39: 162-177.

Wagner, J. A., A. S. Kelly, and R. B. Kelly (1979) Nerve terminal proteins of the rabbit visual relay nuclei identified by axonal transport and two-dimensional gel electrophoresis. Brain Res. 168: 97-117.

Weil, D. E., and D. L. McIlwain (1981) Distribution of soluble proteins within spinal motoneurons: A quantitative twodimensional electrophoretic analysis. J. Neurochem. 36: 242250.

Wilson, D. L., M. E. Hall, G. C. Stone, and R. W. Rubin (1977) Some improvements in two-dimensional gel electrophoresis of proteins. Anal. Biochem. 83: 33-44. 